\title{
PENINGKATAN EKONOMI MASYARAKAT MELALUI PENINGKATAN PRODUKTIFITAS TERNAK SAPI POTONG DI KELURAHAN MERDEKA KECAMATAN KUPANG TIMUR KABUPATEN KUPANG
}

Ferdinan S. Suek, Melkianus D. S. Randu

Program Studi Produksi Ternak, Politeknik Pertanian Negeri kupang

\begin{abstract}
ABSTRAK
Kegiatan ini bertujuan meningkatkan pengetahuan, pemahaman, kesadaran dan keterampilan anggota kelompok tani terutama berkaitan dengan sistem manajemen usaha sapi potong. Implementasi tersebut dilakukan melalui introduksi teknologi perkandangan, pengolahan dan pengawetan pakan, pengolahan limbah ternak, penyebaran informasi sistem pemeliharaan ternak sapi, analisis usaha serta manajemen pembukuan kelompok tani. Fokus kegiatan dilakukan pada Kelompok tani Uis Kefi dan Sone Tuan dengan mengembangkan aspek partisipatif anggota kelompok tani guna percepatan transfer Ipteks. Secara teknis, pelaksanaan kegiatan menggunakan metode ceramah, diskusi, demonstrasi plot (demplot), pendampingan, dan monev. Hasil yang dicapai, meliputi : 1) peningkatan pengetahuan dan pemahaman tentang manfaat kandang ternak sapi; manfaat limbah pertanian - peternakan sebagai pakan dan pupuk organik; manfaat analisis ekonomi dan pembukuan kelompok untuk pengembangan usaha di masa mendatang; 2) Peningkatan kesadaran memanfaatkan limbah pertanian-peternakan yang selama ini tidak digunakan, serta kesadaran mengandangkan ternak sapi yang selama ini diikat di bawah pohon; 3) peningkatan keterampilan anggota kelompok tani dalam pembuatan kandang, pengolahan dan pengawetan pakan hijauan, serta penanganan kesehatan ternak. Luaran yang dihasilkan, antara lain : Produk silase rumput lapangan sebanyak $200 \mathrm{~kg}$, Produk jerami padi fermentasi sebanyak $250 \mathrm{~kg}$, Jasa tenaga pelayanan kesehatan hewan berbasis masyarakat (Yankeswan) sebanyak 2 orang, Produk kandang sapi potong berukuran 1,8 x 2 m sebanyak 2 unit, Produk pupuk organik (Bokashi) menggunakan bahan dasar feces sapi dan arang sekam sebanyak $250 \mathrm{~kg}$, Peningkatan pendapatan alternatif anggota kelompok mitra dari aktivitas pembuatan pupuk bokashi sebesar Rp.300.000,-/minggu.
\end{abstract}

Kata Kunci : Produktivitas Sapi, Ekonomi Masyarakat 


\section{PENDAHULUAN}

\section{Latar Belakang}

Kupang Timur merupakan salah satu diantara 24 kecamatan yang berada di wilayah Kabupaten Kupang, Provinsi Nusa Tenggara Timur. Luas wilayah Kecamatan Kupang Timur adalah 338,60 km² atau 7,3 \% dari luas wilayah Kabupaten Kupang. Sebagaimana kecamatan lainnya, Kupang Timur merupakan daerah yang beriklim tropis dan dipengaruhi oleh angin muson, dengan intensitas bulan basah 3-4 bulan (Desember-Maret) dan bulan kering 8-9 bulan (April-November). Lamanya musim kemarau mempengaruhi jenis flora yang hampir sebagian besar terdiri dari pegunungan dan padang, serta jenis fauna yang terdiri dari ternak besar (sapi, kerbau, dan kuda), ternak kecil (kambing, domba, dan babi), serta unggas (ayam dan itik) (Kupang Timur Dalam Angka, 2014).

Kelurahan Merdeka merupakan salah satu kelurahan di Kecamatan Kupang Timur yang berpotensi untuk pengembangan sektor pertanian. Luas wilayah Kelurahan Merdeka adalah $10,50 \mathrm{~km}^{2}$, dengan jarak menuju Ibu Kota Kecamatan $\pm 1 \mathrm{Km}$ dan menuju Ibu Kota Kabupaten $\pm 11 \mathrm{Km}$. Jumlah penduduk Kelurahan Merdeka pada tahun 2013 berjumlah 2.913 Jiwa dan terdiri dari laki-laki 1.477 jiwa maupun perempuan 1.436 jiwa. Dominasi mata pencaharian masyarakat bersumber di sektor pertanian, melalui budidaya tanaman bahan makanan (padi, jagung, ubi kayu, kacang tanah); sayuran (kubis, petsai, tomat,); buahbuahan (pisang, mangga, pepaya); perkebunan (kelapa, pinang, jambu mente); hutan (balok tuak, jati, asam). Budidaya ternak dilakukan untuk komoditas sapi, babi dan kambing (Kupang Timur Dalam Angka, 2014).

Kelompok mitra Uis Kefi dan Sone Tuan merupakan kumpulan peternak sapi potong yang berada di RT 03, RW 08 Kelurahan Merdeka, Kecamatan Kupang Timur, Kabupaten Kupang. Kelompok mitra tersebut dibentuk sejak tahun 2001 dan bergerak dalam usaha pemeliharaan ternak sapi potong. Pembentukan kelompok mitra Uis Kefi dan Sone Tuan didasari semangat yang sama dalam meningkatkan kesejahteraan peternak maupun membantu mengatasi persoalan sesama anggota kelompok mitra. Pada awal dijalankannya usaha pemeliharaan ternak sapi potong, kelompok mitra Uis Kefi mempunyai jumlah anggota sebanyak 8 orang dengan jumlah ternak sapi yang dimiliki adalah 25 ekor. Demikian pula kelompok mitra Sone Tuan mempunyai jumlah anggota kelompok sebanyak 
9 orang dengan jumlah ternak sapi yang dimiliki adalah 29 ekor. Namun demikian dalam perkembangannya, jumlah anggota kelompok mitra Uis Kefi berkurang menjadi 6 orang dengan ternak sapi yang dimiliki sebanyak 15 ekor. Kelompok Sone Tuan mempunyai 5 anggota kelompok tani dengan jumlah ternak sapi yang dimiliki adalah 11 ekor.

Berkurangnya jumlah anggota kelompok mitra Uis Kefi dan Sone Tuan disebabkan oleh beralihnya usaha beberapa anggota kelompok ke sub sektor pertanian tanaman pangan dan perkebunan yang "dipandang" lebih menguntungkan. Kondisi tersebut secara akumulatif menyebabkan terjadinya perubahan dalam jumlah kepemilikan ternak kelompok secara kolektif. Selain itu berkurangnya jumlah kepemilikan ternak sapi potong anggota kelompok mitra juga diakibatkan oleh kejadian penyakit ternak sapi potong, aktivitas penjualan ternak sapi potong, maupun pemanfaatan ternak sapi potong untuk kebutuhan sosial (pesta, kematian, dan lainnya).

Pemeliharaan sapi potong (Sapi Bali Timor) sebagai komoditas ternak utama yang diusahakan anggota kelompok mitra Uis Kefi dan Sone Tuan, dipandang belum mampu memberikan kontribusi signifikan terhadap peningkatan pendapatan maupun kesejahteraan anggota kelompok mitra. Hal tersebut dipengaruhi oleh sistem manajemen pemeliharaan ternak sapi potong yang masih bersifat tradisional. Padahal aktivitas pemeliharaan ternak sapi merupakan kegiatan rutin turun-temurun yang telah dijalankan selama beberapa tahun. Berdasarkan hasil kunjungan lapangan dan diskusi bersama anggota kelompok mitra Uis Kefi dan Sone Tuan diketahui bahwa aktivitas pemeliharaan ternak sapi potong yang dilakukan selama ini belum mampu meningkatkan produktivitas ternak sapi akibat berbagai faktor dan hambatan.

Rendahnya produktivitas sapi potong yang dipelihara anggota kelompok mitra berkaitan pula dengan dominasi sistem pemeliharaan yang dilakukan dan bersifat semi intensif, dimana ternak dibiarkan di padang penggembalaan pada pagi hari dan ketika sore harinya ternak dibawa kembali ke dalam kandang. Sistem pemeliharaan yang demikian mengakibatkan rendahnya kontrol peternak terhadap ketersediaan pakan, perkawinan, maupun kesehatan ternak. Pemanfaatan berbagai teknologi pakan dalam menyiasati keterbatasan pakan di musim kemarau dan kelimpahan pakan di musim penghujan sama sekali belum dilakukan oleh anggota kelompok mitra Uis Kefi dan Sone Tuan. 
Ketersediaan limbah (by product) rumput lapangan dan batang padi hasil panenan yang banyak tersedia di wilayah Kelurahan Merdeka sebagai sumber pakan alternatif untuk pemeliharaan ternak sapi potong, belum dimanfaatkan secara optimal oleh anggota kelompok mitra Uis Kefi dan Sone Tuan. Kondisi tersebut telah berpengaruh pula kepada lamanya waktu pemeliharaan ternak sapi sebelum dijual yaitu sekitar 10-12 bulan dari yang seharusnya hanya dipelihara selama kurang lebih 3-4 bulan.

Hambatan peningkatan produktivitas sapi potong yang dipelihara mitra juga diakibatkan oleh tingginya kejadian penyakit Septichaemia Epizootica (SE) dan penyakit cacing hati yang dapat dikategorikan sebagai penyakit endemik karena terjadi setiap tahun. Kejadian tersebut selalu menimbulkan kerugian secara fisik (kematian) maupun ekonomis (kehilangan pendapatan) anggota kelompok mitra Uis Kefi dan Sone Tuan. Berbagai upaya mengatasi penyakit ternak sapi potong seringkali menemui kendala terutama berkaitan dengan keterbatasan akses kelompok mitra ke poskeswan, terbatasnya tenaga kesehatan hewan, selain rendahnya pengetahuan dan pemahaman anggota mitra tentang penyebab, gejala, pencegahan, dan pengobatan penyakit ternak sapi potong.

Kondisi perkandangan di kelompok mitra Uis Kefi dan Sone Tuan yang turut menunjang aktivitas pemeliharaan ternak sapi potong masih belum memenuhi syarat teknis perkandangan yang baik, diantaranya belum mempunyai atap kandang, lantai kandang, serta tempat pakan (bak pakan). Hal tersebut berkaitan erat dengan sistem pemeliharaan semi intensif yang dilakukan anggota kelompok mitra sehingga peranan kandang hanya sematamata sebagai tempat berteduh ketika pulang dari padang penggembalaan. Kondisi perkandangan yang demikian, secara tidak langsung turut mempengaruhi pula terhadap pertumbuhan, produktivitas maupun status kesehatan ternak sapi. Sugeng (2004) menyatakan kandang ternak sapi yang baik adalah kandang yang memenuhi syarat teknis diantaranya memiliki atap untuk menaungi ternak dari kondisi panas matahari dan hujan, lantai kandang berukuran 1,8 x $2 \mathrm{~m}$ dan dibuat miring untuk memudahkan pembersihan kandang, serta memiliki tempat pakan.

Kelompok mitra Uis Kefi dan Sone Tuan memiliki potensi yang dapat digunakan sebagai sumber pendapatan alternatif yaitu melalui pengolahan limbah sapi potong. Budiyanto (2011) menyatakan satu ekor ternak sapi setiap harinya menghasilkan kotoran \pm 8 - $10 \mathrm{~kg}$ 
atau 2,6 - 3,6 ton per tahun dan setara dengan 1,5 - 2,0 ton pupuk organik, sehingga apabila dimanfaatkan akan mengurangi penggunaan pupuk anorganik dan mempercepat perbaikan lahan. Dengan demikian, apabila dimanfaatkan, ternak sapi milik mitra dapat menghasilkan 9 kg x 22 ekor $=198 \mathrm{~kg}$ faeces segar perhari. Diasumsikan hasil pengolahan limbah terjadi pengurangan kadar air feces sebesar $75 \%$, maka setiap hari mitra menghasilkan 49,5 kg faeces kering. Melalui pengolahan limbah (bokashi) diharapkan pendapatan anggota mitra bertambah minimal Rp.49.500/hari yang diperoleh dari hasil penjualan bokashi dengan harga Rp.1000/kg.

\section{Perumusan Masalah}

Berdasarkan uraian sebelumnya, dapat dirumuskan beberapa masalah yang berkaitan dengan sistem manajemen pemeliharaan usaha ternak sapi potong di kelompok Tani Uis Kefi dan Sone Tuan, antara lain :

1. Rendahnya pengetahuan dan pemahaman anggota mitra kelompok tani berkaitan dengan sistem manajemen usaha ternak sapi potong.

2. Potensi limbah pertanian dan peternakan yang belum dioptimalkan melalui introduksi teknologi tepat guna untuk mengatasi kelangkaan pakan di musim kemarau sekaligus memunculkan peluang ekonomi alternatif.

3. Rendahnya kesadaran anggota mitra kelompok tani dalam memanfaatkan limbah pertanian dan peternakan dalam kerangka strategi penyediaan pakan yang berkelanjutan.

4. Rendahnya produktivitas ternak sapi akibat sistem pemeliharaan yang masih dilakukan secara tradisional.

5. Tingginya ketergantungan terhadap pupuk urea (an organik) dalam setiap aktivitas pertanian anggota mitra kelompok tani.

6. Rendahnya keterampilan anggota mitra kelompok tani dalam melakukan pengolahan dan pengawetan pakan, pengolahan limbah ternak, perkandangan, analisis usaha dan pembukuan kelompok tani.

\section{Tujuan Kegiatan}

Penerapan Ipteks bagi Masyarakat (IbM) bertujuan meningkatkan pengetahuan, pemahaman, kesadaran maupun keterampilan anggota mitra kelompok tani Uis Kefi dan Sone Tua dalam 
memanfaatkan berbagai potensi limbah pertanian dan peternakan yang tersedia melalui introduksi teknologi dalam kerangka pengembangan sistem manajemen usaha dan peningkatan produktivitas ternak sapi potong.

\section{METODE PELAKSANAAN}

\section{Lokasi dan Waktu Kegiatan.}

Kegiatan penerapan IbM dilaksanakan pada kelompok tani Uis Kefi dan Sone Tuan yang berlokasi di Kelurahan Merdeka, Kecamatan Kupang Timur, Kabupaten Kupang, Provinsi Nusa Tenggara Timur. Kegiatan tersebut dilakukan selama 4 (empat) bulan terhitung sejak tanggal 13 Agustus 2016 sampai dengan 05 November 2016.

\section{Metode Kegiatan.}

Kegiatan IbM menggunakan beberapa metode, sebagai berikut :

1. Metode ceramah melalui penyampaian informasi yang berkaitan langsung dengan pencapaian luaran kepada anggota mitra kelompok tani Uis Kefi dan Sone Tuan. Informasi tersebut berbentuk materi penyuluhan, disampaikan baik secara lisan maupun tulisan (leaflet) oleh tim pelaksana IbM maupun narasumber terkait.

2. Metode diskusi melalui penyampaian pertanyaan kepada tim pelaksana IbM dan narasumber terutama yang berkaitan dengan masalah anggota mitra kelompok tani Uis Kefi dan Sone Tuan maupun terhadap isi materi penyuluhan yang dipandang belum dapat dipahami secara baik.

3. Metode demplot melalui pemberian contoh dan kesempatan kepada anggota mitra kelompok tani Uis Kefi dan Sone Tuan untuk secara bersama-sama mengetahui dan memahami berbagai proses adopsi ilmu pengetahuan teknologi yang diberikan dalam kegiatan IbM.

4. Metode pendampingan, monitoring dan evaluasi pelaksanaan kegiatan yang dilakukan tim pelaksana kegiatan IbM kepada anggota mitra kelompok tani Uis Kefi dan Sone Tuan. 


\section{Prosedur Kegiatan.}

Pelaksanaan IbM mempunyai beberapa prosedur kegiatan , sebagai berikut :

1. Metode ceramah :

a. Pertemuan dan sosialisasi oleh tim pelaksana IbM kepada anggota mitra kelompok tani Uis Kefi dan Sone Tuan menyangkut rencana kegiatan IbM.

b. Pertemuan tim pelaksana IbM untuk menyiapkan narasumber dan materimateri penyuluhan terkait.

c. Pemberian materi penyuluhan kepada anggota mitra kelompok tani Uis Kefi dan Sone Tuan, meliputi : sistem perkandangan ternak sapi, pembuatan silase rumput lapangan, pembuatan jerami fermentasi, pembuatan bokashi pupuk kandang.

2. Metode diskusi :

a. Anggota mitra kelompok tani Uis Kefi dan Sone Tuan mengajukan pertanyaan/contoh masalah yang berkaitan dengan materi penyuluhan.

b. Tim pelaksana IbM maupun narasumber memberikan tanggapan dalam bentuk jawaban atas pertanyaan ataupun solusi terhadap permasalahan yang dihadapi anggota mitra kelompok tani Uis Kefi dan Sone Tuan sekaligus memberikan dukungan atau motivasi terhadap perilaku positif yang mendukung pengembangan aktivitas usaha mitra kelompok tani.

3. Metode demonstrasi plot (demplot):

a. Persiapan alat dan bahan oleh tim pelaksana IbM maupun anggota mitra kelompok tani Uis Kefi dan Sone Tuan.

b. Penjelasan singkat prosedur kerja oleh tim pelaksana IbM maupun narasumber terkait.

c. Anggota mitra kelompok tani Uis Kefi dan Sone Tuan melakukan aktivitas demplot sesuai bimbingan tim pelaksana $\mathrm{IbM}$ dan narasumber.

4. Metode pendampingan, monitoring dan evaluasi :

a. Penyusunan jadwal pendampingan dan monitoring aktivitas kegiatan IbM oleh tim pelaksana. 
b. Pemantauan dan bimbingan teknis terkait pengetahuan dan teknologi yang diintrodusir dalam kegiatan IbM.

c. Evaluasi pelaksanaan demplot untuk mengetahui tingkat penerimaan anggota mitra kelompok tani Uis Kefi dan Sone Tuan terhadap ilmu pengetahuan dan teknologi yang diberikan.

d. Evaluasi permasalahan dan kendala selama pelaksanaan kegiatan IbM disertai pemberian solusi.

\section{HASIL DAN PEMBAHASAN}

Program Ipteks bagi Masyarakat (IbM) sebagai salah satu bentuk pengabdian yang ditujukan untuk anggota kelompok tani Uis Kefi dan Sone Tuan di Kelurahan Merdeka, Kecamatan Kupang Timur, Kabupaten Kupang, Provinsi Nusa Tenggara Timur bertujuan untuk meningkatkan pengetahuan, pemahaman, kesadaran dan keterampilan anggota mitra kelompok tani terutama yang berkaitan dengan sistem manajemen usaha ternak sapi potong. Hal tersebut menjadi penting dalam kerangka mempercepat transformasi sikap, perilaku dan keterampilan yang mendukung upaya peningkatan produktivitas ternak sapi dan pengembangan usaha mitra kelompok tani.

Pencapaian hasil pelaksanaan IbM di Kelompok Tani Uis Kefi dan Sone Tuan tercermin dari peningkatan produktivitas ternak sapi milik mitra, peningkatan partisipasi dan pemahaman anggota mitra kelompok tani dalam mengikuti seluruh rangkaian kegiatan penyuluhan dan demplot IbM. Pengamatan yang sampai akhir kegiatan menemukan indikasi kesadaran dari anggota mitra kelompok tani untuk mengandangkan ternak dan memanfaatkan silase maupun jerami padi fermentasi sebagai pakan ternak sapi milik anggota mitra. Hal tersebut diindikasikan dari peningkatan bobot badan ternak sapi yang dikandangkan serta diberikan silase jagung + jerami padi fermentasi sebesar $\pm 0,5 \mathrm{~kg} / \mathrm{hari}$. Hal lainnya yang juga turut menjadi perhatian adalah kesadaran untuk menjaga kontinuitas pakan pada musim kemarau melalui pemanfaatan teknologi pengolahan dan pengawetan pakan. 
Aspek pengolahan limbah peternakan juga telah memberikan dampak positif bagi anggota mitra kelompok tani Uis Kefi dan Sone Tuan terutama dalam hal pembuatan bokashi secara mandiri, ujicoba pemberian bokashi pada tanaman jagung yang selama ini selalu diberikan pupuk an organik (pupuk kimia), maupun upaya pemasaran produk bokashi yang dihasilkan.

Hasil pelaksanaan kegiatan IbM di kelompok tani Uis Kefi dan Sone Tuan, Kelurahan Merdeka, Kecamatan Kupang Timur, Kabupaten Kupang, Provinsi Nusa Tenggara Timur dapat dilihat pada tabel 1 .

Tabel 1. Hasil Pelaksanaan IbM Kelompok Tani Uis Kefi dan Sone Tuan.

\begin{tabular}{|c|c|c|}
\hline No & Jenis Kegiatan & Hasil yang dicapai \\
\hline 1. & $\begin{array}{l}\text { Penyuluhan } \\
\text { dan Demplot } \\
\text { Pembuatan Silase } \\
\text { rumput lapangan }\end{array}$ & $\begin{array}{l}\text { 1. Produksi silase sebanyak } 200 \mathrm{Kg} \text {. } \\
\text { 2. Pengetahuan mitra tentang manfaat silase } \\
\text { jagung sebagai sumber pakan ternak sapi. } \\
\text { 3. Kemampuan mitra membuat silase jagung. } \\
\text { 4. Pengetahuan mitra tentang ciri fisik silase } \\
\text { yang baik. } \\
\text { 5. Pemahaman mitra tentang pentingnya strategi } \\
\text { penyediaan pakan yang berkelanjutan di musim } \\
\text { kemarau. } \\
\text { 6. Kesadaran mitra memanfaatkan rumput } \\
\text { lapangan yang selama ini belum diolah. }\end{array}$ \\
\hline 2 & $\begin{array}{l}\text { Penyuluhan } \\
\text { dan Demplot } \\
\text { Pembuatan Jerami } \\
\text { Padi Fermentasi }\end{array}$ & $\begin{array}{l}\text { 1. Produksi jerami padi fermentasi sebanyak } \\
\text { 250 Kg. } \\
\text { 2. Pengetahuan mitra tentang manfaat jerami } \\
\text { padi fermentasi sebagai sumber pakan ternak } \\
\text { sapi di musim kemarau. } \\
\text { 3. Kemampuan mitra membuat jerami padi } \\
\text { fermentasi menggunakan limbah tanaman padi. } \\
\text { 4. Pengetahuan mitra tentang ciri fisik jerami } \\
\text { padi fermentasi. } \\
\text { 5. Pemahaman mitra tentang strategi } \\
\text { penyediaan pakan yang berkelanjutan di musim } \\
\text { kemarau. } \\
\text { 6. Kesadaran memanfaatkan limbah tanaman } \\
\text { padi yang selama ini belum diolah secara } \\
\text { baik (dibakar). }\end{array}$ \\
\hline 3. & $\begin{array}{l}\text { Penyuluhan } \\
\text { dan Demplot }\end{array}$ & $\begin{array}{l}\text { 1. Produksi bokashi sebanyak } 250 \mathrm{Kg} \text {. } \\
\text { 2. Pengetahuan mitra tentang manfaat bokashi }\end{array}$ \\
\hline
\end{tabular}




\begin{tabular}{|c|c|c|}
\hline & $\begin{array}{l}\text { Pembuatan Pupuk } \\
\text { Organik (Bokashi) }\end{array}$ & $\begin{array}{l}\text { sebagai pupuk organik dan sumber pendapatan } \\
\text { alternatif rumah tangga. } \\
\text { 3. Kemampuan mitra membuat bokashi } \\
\text { menggunakan limbah ternak sapi (faeces) dan } \\
\text { limbah hasil penggilingan bulir padi. } \\
\text { 4. Pemahaman mitra tentang pemanfaatan bokashi } \\
\text { untuk mengembalikan kondisi tanah yang } \\
\text { "kering" akibat penggunaan pupuk anorganik. } \\
\text { 5. Kesadaran mitra menjual bokashi sebagai } \\
\text { salah satu sumber pendapatan alternatif rumah } \\
\text { tangga petani. }\end{array}$ \\
\hline 4. & $\begin{array}{l}\text { Penyuluhan } \\
\text { dan Demplot } \\
\text { Pembuatan Kandang } \\
\text { Sapi Penggemukan }\end{array}$ & $\begin{array}{l}\text { 1. Tersedianya kandang sapi individu untuk } \\
\text { kegiatan paronisasi sebanyak } 4 \text { (empat) unit. } \\
\text { 2. Pengetahuan mitra tentang manfaat kandang } \\
\text { untuk mendukung produktivitas ternak sapi yang } \\
\text { dipelihara dengan sistem paronisasi. } \\
\text { 3. Kemampuan mitra membuat kandang sapi } \\
\text { individu sesuai syarat teknis perkandangan yang } \\
\text { sesuai. } \\
\text { 4. Kesadaran mitra mengandangkan ternak sapi } \\
\text { sebagai upaya mempercepat waktu paronisasi }\end{array}$ \\
\hline 5. & $\begin{array}{l}\text { Penyuluhan tentang } \\
\text { pelayanan kesehatan } \\
\text { hewan }\end{array}$ & $\begin{array}{l}\text { 1. Adanya peningkatan kemampuan mitra dalam } \\
\text { penanganan kesehatan ternak sapi } \\
\text { 2. Tersedianya obat-obatan dan alat suntik ternak }\end{array}$ \\
\hline 7. & $\begin{array}{l}\text { Publikasi melalui } \\
\text { media lokal maupun } \\
\text { jurnal }\end{array}$ & \\
\hline
\end{tabular}

Meskipun demikian, secara teknis terdapat pula beberapa kendala yang dialami selama rangkaian pelaksanaan kegiatan IbM yang sekiranya menjadi evaluasi dan perbaikan tersendiri bagi pelaksanaan kegiatan pada masa mendatang. Berbagai kendala dimaksud, antara lain :

1. Perubahan jadwal yang telah disepakati sebelumnya bersama pengurus kelompok tani Uis Kefi dan Sone Tuan akibat kegiatan isidentil (mendadak) yang tidak dapat dihindari oleh sebagaian besar anggota kelompok tani seperti kedukaan dan perkawinan.

2. Aktivitas isidentil (mendadak) yang harus dijalankan oleh masing-masing tim pelaksana IbM sehingga berdampak kepada penundaan waktu bahkan jadwal pelaksanaan kegiatan di kelompok tani Uis Kefi dan Sone Tuan. 


\section{KESIMPULAN DAN SARAN}

\section{Kesimpulan}

Pelaksanaan kegiatan ipteks bagi masyarakat ( $\mathrm{IbM}$ ) telah memberikan manfaat positif terutama dalam kerangka pengelolaan sistem manajemen usaha di Kelompok mitra Uis Kefi dan Sone Tuan. Hal tersebut dilakukan melalui pemanfaatan kandang (penggemukan), silase jagung, jerami padi fermentasi, bokashi pupuk kandang, analisis usaha maupun pembukuan kelompok tani.

\section{Saran}

Berdasarkan hasil kegiatan IbM disarankan perlu dilakukannya pengembangan introduksi teknologi secara berkelanjutan melalui penerapan sistem usaha tani terpadu yang memanfaatkan limbah hasil pertanian. Selain itu, di masa mendatang sekiranya perlu dipertimbangkan kegiatan IbM lanjutan untuk pembuatan biogas sebagai sumber energi alternatif dari ternak sapi milik kelompok yang telah dikandangkan.

\section{UCAPAN TERIMA KASIH}

Keberhasilan pelaksanaan kegiatan IbM merupakan hasil dukungan, kerjasama dan dorongan berbagai pihak. Untuk itu selaku tim pelaksana, kami menyampaikan terima kasih dan penghargaan yang setinggi-tingginya kepada :

1. Direktur Penelitian dan Pengabdian Kepada Masyarakat - Dirjen Dikti Kementerian Riset Teknologi dan Pendidikan

2. Kepala Pusat P2M Politeknik Pertanian Negeri Kupang.

3. Bapak Frans Falukas dan Bapak Sinyo Falukas sebagai Ketua Kelompok Tani Uis Kefi dan Sone Tuan atas bantuan fasilitas maupun kerjasamanya selama proses kegiatan IbM.

4. Anggota kelompok tani Uis Kefi dan Sone Tuan atas partisipasi aktif selama mengikuti kegiatan penyuluhan dan demplot IbM.

5. Dosen, teknisi, mahasiswa Jurusan Peternakan, atas partisipasinya baik sebagai pemateri maupun pendamping dalam seluruh kegiatan IbM. 


\section{DAFTAR PUSTAKA}

Anonimous, 2008. Hijauan Makanan Ternak. http:// www.disnak.jabarprov.go.id/images/artikel/hijauan.doc. Diakses 05 September 2012.

Anonimous, 2008. Produksi Biogas dari Limbah Ternak. Inforomasi Paket teknologi. Pusat penelitian Kopi dan Kako Indonesia. http://pustaka.litbang. deptan.go.id/agritek/kopi08.pdf. Diakses 12 April 2013.

Anonimous, 2012. Kabupaten Kupang dalam Angka Tahun 2011. Badan Pusat Statistik Kabupaten Kupang. Kupang.

Sugeng, 2004. Sapi potong. Penerbit PT. Penebar Swadaya, Jakarta. 